\title{
Pasture degradation of the Southern Kulunda steppes (Altai Krai) Elesova N.V.
}

\author{
Altai State University, 61 Lenina prospect, Barnaul, 656049, Russia. \\ E-mail: elesovanv@mail.ru
}

Received: 14.08.2019. Accepted: 26.09.2019

\begin{abstract}
The article considers the results of the study of degraded bunchgrass steppes state in the Southern Kulunda area (2013-2018). It points out stages of the grassland degradation and estimates changes in the following: species composition, vertical and horizontal grass stand structure, supply of the aboveground phytomass as a result of pasture load growth.
\end{abstract}

Key words: Steppe pastures; Degradation; Pasture degradation stages; Southern Kulunda

\section{Introduction}

Steppe pastures of the Southern Kulunda, being valuable forage lands, are not used in full compliance with the sustainability standards. Continuous unregulated grazing leads to significant pasture degradation. As a result, native steppe communities are replaced by secondary low-yielding ones that have lost any forage value. In the Southern Kulunda, the zonal vegetation type is the true bunchgrass steppe, greatly degraded as a result of overgrazing. Some parts of steppes are used for haying. Resulting from continuous disorganized exploitation of the steppe cenoses, the majority of the pastures in the area are at the stage of heavy grazing and at the stage of overgrazing near villages and cattle stands. The term "pasture degradation" was proposed by G.N. Vysotskiy (1915), the stages of pasture degradation were first identified by I.K. Pachoskiy (1917), the consequences of pasture degradation are described in the works of Ivanov (1958), Gorshkova (1954, 1957), Gorshkova, Grineva (1977) and others.

\section{Materials and Methods}

A plot of bunchgrass degraded steppe, situated $5 \mathrm{~km}$ west of the Poluyamki village (Mikhaylovskiy district), was selected to conduct experiments in studying the pasture lands state. The land area is 65 ha.

In May 2013, three monitoring sites corresponding to different stages of pasture degradation (I - moderate to no grazing, II - heavy grazing, III - heavy grazing to overgrazing) and placed along the ecological profile towards the cattle camp were allocated in the area. About $80 \%$ of the selected plot is the wormwood-fescue degraded steppe (the heavy grazing stage). The degree of pasture load increases in the direction from the windbreak strip to the cattle stand.

In 2013-2018 during 6 growing seasons from May to August, monthly geobotanical monitoring of pasture phytocenoses and assessment of the aboveground phytomass supply (green shoots, dead grass and ground litter) were carried out.

In June 2013, the true forb-fescue-feather grass steppe (Heterocherbae + Festuca valesiaca - Stipa capillata) corresponding to stage I of pasture degradation - moderate grazing, was described on the plot, farthest from the cattle stand (at the beginning of the ecological profile). The soil is chestnut solonetz. 36 species of plants are registered on $100 \mathrm{~m}^{2}$. The total projective cover (TPC) is $55-60 \%$, occasionally reaching $70 \%$. Grass stand edificators are Stipa capillata L. (PC - projective cover is 10-15\%), Festuca valesiaca Gaudin (PC is 25\%). The grass stand is three-layered. The legumes represented in the grass stand are Medicago falcat L., Oxytropis pilosa (L.) DC, Astragalus buchtormensis Pall., Onobrychis arenaria (Kit.) DC.

The plot of alfalfa-wormwood-fescue steppe (Medicago falcata + Artemisia pontica + Festuca valesiaca) is at the second stage of pasture degradation (heavy grazing). The soil is chestnut solonetz. The TPC equals to $45-50 \%$. In June 2013,23 plant species were registered per $100 \mathrm{~m}^{2}$.

Grass stand edificators are Medicago falcata (6\%), Artemisia pontica L. (10\%), Festuca valesiaca (20\%). The grass stand is twolayered. Among the legumes, Onobrychis arenaria and Astragalus buchtormensis occur along with Medicago falcata.

The plot of the fescue-wormwood highly degraded steppe (Festuca valesiaca + Artemisia austriaca) corresponds to the third stage of pasture degradation with the transition to the fourth stage (poaching). Almost no steppe litter is observed. The soil is chestnut solonetz. The TPC is $30-35 \%$. In June 2013, 17 plant species were registered per $100 \mathrm{~m}^{2}$. Conventionally, 2 sublayers can be distinguished in the grass stand. Grass stand edificators are Artemisia austriaca Jacq. (8-10\%), Festuca valesiaca (15\%). The following works provide a more detailed description of the monitoring plots, research methods and intermediate results: (Elesova et al., 2014; Elesova, Silantyeva, 2015; Elesova et al., 2018).

\section{Results and Discussion}

In June 2018, we carried out geobotanical descriptions of steppe pastures at different stages of degradation. In the plot, farthest from the cattle stand (at the beginning of the ecological profile), we observed the true centaury-bluegrass-fescue steppe (Centaurea scabiosa-Poa angustifolia + Festuca valesiaca), which corresponds to stage I of pasture degradation - moderate grazing. The soil is chestnut solonetz. The TPC is $65-70 \%$. 
The grass stand is three-layered. The first $85-\mathrm{cm}$-high sublayer is formed by Centaurea scabiosa, Stipa capillata, Glycyrrhiza uralensis Fisch. and others. The second $40-\mathrm{cm}$-high sublayer is formed by Koeleria cristata (L.) Pers., Poa angustifolia, Festuca valesiaca and others. Potentilla humifusa Willd., Potentilla bifurca L., Artemisia austriaca, etc. are found in the third sublayer reaching $20 \mathrm{~cm}$ in height. The following legumes occur in the grass stand: Medicago falcata, Oxytropis pilosa, Glycyrrhiza uralensis, Melilotus officinale (L.) Pall., Onobrychis arenaria. Sedges are represented by Carex supina Willd. ex Wachlend.

The forbs group (27 species) includes Centaurea scabiosa, Galium ruthenicum Willd., Scabiosa ochroleuca L., Salvia stepposa Shost., Potentilla humifusa, Potentilla bifurca, Potentilla canescens Bess., Eryngium planum L., Otites parviflora (Ehrh.) Grossh., Erygeron acris L., Nonea rossica Stev., Achillea setacea Waldst., Veronica spuria L., Euphrasia pectinata Ten., Jacobaea erucifolia (L.) Gaertn, Plantago media L., Berteroa incana L., Euphorbia virgata Waldst. et Kit., Artemisia austriaca Jacq., Artemisia glauca Pall. ex Willd., Artemisia pontica L. In total, the grass stand features 30 species of higher vascular plants per $100 \mathrm{~m}^{2}$.

The plot of the wormwood-alfalfa-fescue steppe (Artemisia austriaca-Medicago falcata + Festuca valesiaca) is at the second stage of pasture degradation (heavy grazing). The soil is dark chestnut solonetz. The TPC is $55-60 \%$.

The grass stand is three-layered. The first sublayer reaching $70 \mathrm{~cm}$ in height is formed by Elytrigia repens (L.) Nevski, Agropyron pectinatum (Bieb.) Beauv., Salvia stepposa, Centaurea scabiosa, etc. The second sublayer of 35-40 cm encompasses Poaceae Koeleria cristata, Poa angustifolia, Festuca valesiaca and the steppe forbs. The third 15-cm-high sublayer is composed of Potentilla humifusa, Cleistogenes squarrosa (Trin.) Keng, Artemisia austriaca, etc.

The Poaceae group (5 species) includes Festuca valesiaca, Elytrigia repens, Agropyron pectinatum, Koeleria cristata, Poa angustifolia. Legumes are represented by Medicago falcata, Melilotus officinale, Astragalus onobrychis L.

The forbs group (17 species) comprises Centaurea scabiosa, Eryngium planum L., Galium ruthenicum, Salvia stepposa, Berteroa incana, Jacobaea erucifolia, Nonea rossica, Achillea setacea, Herniaria polygama J. Gay., Artemisia austriaca, Artemisia glauca Pall. Ex Willd., Artemisia sieversiana Willd., Artemisia nitrosa Web. Sedges are represented by Carex supina. In total, 21 species of higher vascular plants occur in the grass stand per $100 \mathrm{~m}^{2}$.

The plot of the complex wormwood-fescue and fescue-wormwood highly degraded steppes (Festuca valesiaca + Artemisia austriaca) corresponds to the third stage - the transition to the fourth stage of pasture degradation. It almost completely lacks the steppe ground litter. The soil is dark chestnut solonetz. The TPC equals to 50\%. The grass stand edificators are Artemisia austriaca (15\%), Festuca valesiaca (18\%) (Tables 1-5).

Table 1. Dynamics of the aboveground phytomass supply in the dry bunchgrass steppe (moderate grazing stage)

\begin{tabular}{lcccccc}
\hline Year & $\mathbf{2 0 1 3}$ & $\mathbf{2 0 1 4}$ & $\mathbf{2 0 1 5}$ & $\mathbf{2 0 1 6}$ & $\mathbf{2 0 1 7}$ & $\mathbf{2 0 1 8}$ \\
$\begin{array}{c}\text { Aboveground } \\
\text { phytomass }\end{array}$ & 194.05 & 137.96 & 324.5 & 297.4 & 316.2 & 521.6 \\
Green shoots & 115.74 & 98.34 & 208.5 & 198.2 & 245.8 & 363.2 \\
Dead grass & 1.48 & 2.41 & 9.1 & 38.9 & 17.2 & 18.4 \\
Ground litter & 76.83 & 37.21 & 106.9 & 60.3 & 53.2 & 140.0 \\
\hline
\end{tabular}

Table 2. Dynamics of the aboveground phytomass supply in the dry bunchgrass steppe (heavy grazing stage)

\begin{tabular}{lcccccc}
\hline \multicolumn{1}{c}{ Year } & $\mathbf{2 0 1 3}$ & $\mathbf{2 0 1 4}$ & $\mathbf{2 0 1 5}$ & $\mathbf{2 0 1 6}$ & $\mathbf{2 0 1 7}$ & $\mathbf{2 0 1 8}$ \\
$\quad \begin{array}{l}\text { Aboveground } \\
\text { phytomass }\end{array}$ & 114.12 & 100.39 & 151.1 & 143.2 & 235.4 & 300.0 \\
Green shoots & 67.85 & 57.91 & 93.7 & 88.9 & 152.6 & 195.0 \\
Dead grass & 1.94 & 1.54 & 6.6 & 14.0 & 7.6 & 3.4 \\
Ground litter & 44.33 & 40.94 & 50.8 & 40.3 & 40.3 & 101.6 \\
\hline
\end{tabular}

Two sublayers are identified in the grass stand. Gypsophylla paniculata L., Artemisia commutata Bess form the first sublayer reaching $45 \mathrm{~cm}$ in height. The second sublayer of $20-25 \mathrm{~cm}$ is formed by all the other steppe plants including Poaceae: Festuca valesiaca, Agropyron pectinatum, Medicago falcata, Artemisia austriaca, Artemisia frigida, Berteroa incana, Galium ruthenicum, Taraxacum bessarabicum, Euphorbia virgata. In total, 11 species of higher vascular plants are represented in the grass stand per $100 \mathrm{~m}^{2}$.

Table 3. Dynamics of the aboveground phytomass supply in the dry bunchgrass steppe (heavy grazing stage - transition to overgrazing stage)

\begin{tabular}{lcccccc}
\hline \multicolumn{1}{c}{ Year } & $\mathbf{2 0 1 3}$ & $\mathbf{2 0 1 4}$ & $\mathbf{2 0 1 5}$ & $\mathbf{2 0 1 6}$ & $\mathbf{2 0 1 7}$ & $\mathbf{2 0 1 8}$ \\
$\begin{array}{c}\text { Aboveground } \\
\text { phytomass }\end{array}$ & 47.94 & 48.44 & 112.2 & 103.2 & 97.0 & 190.8 \\
Green shoots & 38.8 & 19.46 & 85.0 & 50.4 & 62.2 & 118.0 \\
Dead grass & 0.7 & 0.79 & 6.7 & 7.1 & 4.4 & 2.6 \\
Ground litter & 8.34 & 28.19 & 20.5 & 45.7 & 30.4 & 70.2 \\
\hline
\end{tabular}


Table 4. Main indicators of the dry bunchgrass steppe at different stages of pasture degradation (Mikhaylovskiy district, precincts of the Poluyamki village, $2013, \mathrm{~g} / \mathrm{m}^{2}$ )

\begin{tabular}{|c|c|c|c|c|c|c|c|c|c|}
\hline $\begin{array}{c}\text { Degradation } \\
\text { stage }\end{array}$ & Association & $\begin{array}{l}\text { Number of } \\
\text { layers }\end{array}$ & Height & $\begin{array}{c}\text { Number of } \\
\text { species }\end{array}$ & TPC & APh & $\begin{array}{l}\text { Green } \\
\text { shoots }\end{array}$ & $\begin{array}{l}\text { Dead } \\
\text { grass }\end{array}$ & $\begin{array}{l}\text { Ground } \\
\text { litter }\end{array}$ \\
\hline I & $\begin{array}{c}\text { forb-fescue- } \\
\text { feather grass } \\
\text { alfalfa- }\end{array}$ & 3 & $50-65$ & 36 & $\begin{array}{c}55-60 \\
(70)\end{array}$ & 194.05 & 115.74 & 1.48 & 76.83 \\
\hline II & $\begin{array}{l}\text { wormwood- } \\
\text { fescue }\end{array}$ & 2 & 25 & 23 & $45-50$ & 114.12 & 67.85 & 1.94 & 44.33 \\
\hline III & $\begin{array}{l}\text { wormwood- } \\
\text { fescue, } \\
\text { fescue- } \\
\text { wormwood }\end{array}$ & 2 & $15-20$ & 17 & $30-35$ & 47.94 & 38.8 & 0.7 & 8.34 \\
\hline
\end{tabular}

Table 5. Main indicators of the dry bunchgrass steppe at different stages of pasture degradation (Mikhaylovskiy district, precincts of the Poluyamki village, $2018, \mathrm{~g} / \mathrm{m}^{2}$ )

\begin{tabular}{|c|c|c|c|c|c|c|c|c|c|}
\hline $\begin{array}{l}\text { Degradation } \\
\text { stage }\end{array}$ & Association & $\begin{array}{l}\text { Number of } \\
\text { layers }\end{array}$ & Height & $\begin{array}{l}\text { Number of } \\
\text { species }\end{array}$ & TPC & APh & $\begin{array}{l}\text { Green } \\
\text { shoots }\end{array}$ & $\begin{array}{l}\text { Dead } \\
\text { grass }\end{array}$ & $\begin{array}{l}\text { Ground } \\
\text { litter }\end{array}$ \\
\hline 1 & $\begin{array}{l}\text { centaury-bluegrass- } \\
\text { fescue steppe }\end{array}$ & 3 & 85 & 30 & $\begin{array}{l}65- \\
70\end{array}$ & 521.6 & 363.2 & 18.4 & 140.0 \\
\hline II & $\begin{array}{c}\text { wormwood-alfalfa- } \\
\text { fescue }\end{array}$ & 3 & 70 & 21 & $\begin{array}{l}55- \\
60\end{array}$ & 300.0 & 195.0 & 3.4 & 101.6 \\
\hline III & wormwood-fescue & 2 & 45 & 11 & 45 & 190.8 & 118.0 & 2.6 & 70.2 \\
\hline
\end{tabular}

In the dry bunchgrass steppes of the Southern Kulunda, the following stages of pasture degradation were identified:

I - The moderate grazing stage (feather grass stage). The true centaury-bluegrass-fescue steppe corresponds to this stage; 31 species of plants were recorded per $100 \mathrm{~m}^{2}$ in July 2018 . The total projective cover is $65-70 \%$. The grass stand is three-layered; the height of the first, the second, and the third sublayers is 85,40 and $20 \mathrm{~cm}$ respectively.

II - The heavy grazing stage (fescue stage). The wormwood-alfalfa-fescue steppe corresponds to this stage. In July 2018,21 species of higher vascular plants were registered per $100 \mathrm{~m}^{2}$. The total projective cover varies from 55 to $60 \%$. The grass stand is composed of three layers; the height of the first sublayer is $70 \mathrm{~cm}$, the second one is $35-40 \mathrm{~cm}$, and the third one is $15 \mathrm{~cm}$.

III - The heavy grazing stage, transition to the overgrazing stage (wormwood stage). The complex wormwood-fescue and fescuewormwood degraded steppe corresponds to this stage; 11 plant species were registered per $100 \mathrm{~m}^{2}$ in July 2018 . The total projective cover is $45 \%$. The grass stand is two-layered; the height of the first sublayer is $45 \mathrm{~cm}$, the height of the second one is 20 $25 \mathrm{~cm}$.

IV - The overgrazing stage (poaching). The frosted orache (Atriplex tatarica L.), forb- frosted orache (Heterocherbae + Atriplex tatarica), bur buttercup-frosted orache (Ceratocephala testiculata + Atriplex tatarica) steppes correspond to this stage. The grass stand is one-layered, $10-15 \mathrm{~cm}$ high. It is mainly comprised of non-eatable plants; 5 plant species were registered per $100 \mathrm{~m}^{2}$ in July 2018. The TPC is $10-15 \%$, but it can reach $80 \%$ due to the growth of non-eatable Atriplex tatarica, Chorispora tenella, Ceratocephala testiculata.

\section{Conclusion}

Continuous unregulated grazing leads to significant pasture degradation. Overgrazing results in the reduction of the total plant species number, which decreases 3 times, from 30 to 11 species, mainly due to sod grasses (Stipa pennata L., Stipa capillata, Koeleria cristata, Poa angustifolia) and forbs. The number of legume species also declines, Medicago falcata is the only representative of the legumes synusia at the third stage. The pasture area features Medicago falcata, Oxytropis pilosa, Glycyrrhiza uralensis, Melilotus officinale, Onobrychis arenaria at the first stage; the ephemeroid Astragalus buchtormensis blooms in spring. Disorganized grazing leads to the simplification of the horizontal and vertical steppe communities structure: the total projective cover decreases 1.5 times (from $65-70 \%$ to $45 \%$ ) from the moderate grazing stage (I) to the heavy grazing - overgrazing stage (III). In addition, the number of layers and their height decrease from stage to stage: at the stage of moderate grazing, the grass stand consists of 3 sublayers, but already at stage III it is conventionally possible to distinguish 2 sublayers, at the overgrazing stage (IV) all plants are located in one layer. The most disorganized grazing affects the yielding capacity of the pasture grass stands: the total supply of the aboveground phytomass is reduced 2.7 times, including the supply of green shoots that is reduced thrice (361.2 and $118.0 \mathrm{~g} / \mathrm{m}^{2}$ respectively). The supply of mortmass is sharply decreased: that of the dead grass is shrunk 7 times, that of the ground litter is shrunk twice. The most efficient measure to combat pasture degradation is the rotational grazing system, the introduction of which will preserve the forage quality of pastures and will increase their capacity by approximately $30 \%$ (Gorshkova et al., 1977). 


\section{References}

Elesova, N.V., Silantyeva, M.M. (2015). The influence of short-term isolation on the vegetation of degraded pastures in Southern Kulunda. Steppes of Northern Eurasia. Proceedings of the VII international symposium. Orenburg, Dimur. (In Russian).

Elesova, N.V., Silantyeva, M.M., Kornyevskaya, T.V. (2018). Ways of degraded pastures restoration in the conditions of the dry steppe zone of Kulunda. Steppes of Northern Eurasia. Proceedings of the VIII international symposium. Orenburg. (In Russian).

Elesova, N.V., Silantyeva, M.M., Speranskaya, N.Yu., Grebennikova, A.Yu. (2014). Assessment and possible ways of the degraded pasture restoration in the dry steppe conditions of Kulunda. Bulletin of Altai Science, 1, 223-228. (In Russian).

Gorshkova, A.A. (1954). Materials for the study of steppe pastures in the Voroshilovgradskaya oblast in connection with their improvement. Proceedings of the Biological Institute of the USSR Academy of Sciences. Geobotany. Leningrad. (In Russian).

Gorshkova, A.A. (1957). Pasture degradation of natural phytocenoses in the conditions of the Balagan forest-steppe. Bulletin of Eastern Branch of the USSR Academy of Sciences, 2, 109-114. (In Russian).

Gorshkova, A.A., Grineva N.F., et al. (1977). Ecology and pasture degradation of the steppe communities in Zabaikalye. Novosibirsk, Nauka. (In Russian).

Ivanov, V.V. (1958) Steppes of Western Kazakhstan in connection with the dynamics of their cover. Moscow - Leningrad. (In Russian).

Pachoskiy, I.K. (1917). Description of the Kherson province vegetation. Volume 2. Kherson. (In Russian).

Vysotskiy, G.N. (1915). Yergenya. Cultural and phytological essay. Proceedings of the Applied Botany Bureau. Saint Petersburg. (In Russian).

\section{Citation:}

Elesova N.V. (2019). Pasture degradation of the Southern Kulunda steppes (Altai krai). Ukrainian Journal of Ecology, 9(3), 356-359. 